Roula Khadra ORCID iD: 0000-0003-2117-1557

\title{
Development and application of a predictive model for treated wastewater irrigation management in a semi-arid area
}

\author{
Giovanna Dragonetti $^{1}$, Roula Khadra ${ }^{1 *}$, André Daccache ${ }^{2}$, Abdellah Oubelkacem ${ }^{1,3}$, \\ Redouane Choukrallah ${ }^{3}$, Nicola lamaddalena ${ }^{1}$ \\ ${ }^{1}$ CIHEAM - Mediterranean Agronomic Institute of Bari, Department of Land and Water \\ Resources Management, Via Ceglie 9, 70010 Valenzano, Italy \\ ${ }^{2}$ University of California, Davis, Department of Biological and Agricultural Engineering, \\ 3056 Bainer Hall, 95616, Davis, California \\ ${ }^{3}$ Institut Agronomique et Vétérinaire Hassan II, Salinity \& Plant nutrition Laboratory, \\ km 2, route de Taroudant, Ait-Melloul, Agadir, Morocco \\ *corresponding author
}

\section{Acknowledgement}

This research was carried out in the framework of the MADFORWATER project EU Horizon 2020 Research and Innovation program funded by the European Commission. A deep gratitude is ought to the staff of CHA-IAV Hassan II, ORMVA Souss Massa and local agricultural cooperatives for providing all necessary data.

The authors declare that they have no conflict of interest.

\section{Abstract}

The use of treated wastewater (TWW) as an alternative resource to freshwater (FW) for irrigation purposes is becoming increasingly important, especially in semiarid and arid regions. However, achieving success in crop production largely depends on the adoption of appropriate on-farm management strategies aimed at optimizing crop yields,

This article has been accepted for publication and undergone full peer review but has not been through the copyediting, typesetting, pagination and proofreading process, which may lead to differences between this version and the Version of Record. Please cite this article as doi: 10.1002/ieam.4307.

This article is protected by copyright. All rights reserved. 
maintaining soil productivity and safeguarding the environment. For this purpose, predictive models are of particular interest. A safe irrigation management (SIM) model developed and tested in this research was used to schedule irrigation under controlled management tailored to the use of i) TWW and ii) FW and to reproduce farmers' strategies. These management strategies aim to improve actual irrigation practices, accounting for water quality, soil characteristics and crop yield. The results of the application of SIM on a citrus farm in Souss-Massa, Morocco, show that the management strategy adopted by farmers withdraws considerable amounts of water and results in substantial drainage volumes compared to those in the SIM strategy. In the specific case of TWW, the strategy simulated by the SIM model resulted in a decrease in yield of approximately $4 \%$, compared to the $23 \%$ decrease derived from the farmers' traditional strategy. Moreover, SIM allowed for great savings in terms of fertilizing elements and for the reduction in the movement of water and salts beyond the root zone, usually considered the main source of groundwater contamination. These results confirm the appropriateness of using prediction models and the accuracy of the SIM model in adapting irrigation strategies to TWW, which will be an integral part of the strategies that encourage their use in irrigated agriculture.

\section{Keywords:}

SIM model, Water scarcity, Soil salinity, Morocco, Citrus.

\section{Key points:}

- A model is developed that incorporates subroutines for i) irrigation scheduling with treated wastewater, accounting for water quality and soil properties and combining water and salt conservation equations, and ii) simulating bacterial movement and assessing the infection risk of exposed farmers.

- For the first time, accurate irrigation management scenarios are defined that are This article is protected by copyright. All rights reserved. 
tailored specifically to the use of treated wastewater on citrus, a strategic crop for SoussMassa that is experiencing a growing deficit of water resources.

- The appropriateness of using accurate prediction models that enable the adaptation of irrigation strategies to TWW is confirmed, which paves the way for field research to further encourage TWW use in irrigated agriculture, especially on highwater-demanding crops in semiarid and arid areas.

- It is confirmed that the SIM model is an effective and powerful tool that supports the development of irrigation strategies to limit soil salinization effects and recover soil quality under TWW.

\section{Introduction}

The reduction in annual precipitation and accentuated climate change effects, such as droughts, have driven consumers in arid and semiarid regions to use alternative water resources in irrigated agriculture, including treated wastewater (TWW) (Thiébault et al. 2016; Milano et al., 2012; IPCC 2014).

In these areas, the reuse of TWW for irrigation could contribute to mitigating/decreasing water shortages and minimizing the pressure on groundwater, as agriculture consumes almost $70 \%$ of the total available water resources (Pimentel and Pimentel 2007). In addition, TWW provides renewable nutrients and organic matter useful for maintaining soil fertility and productivity (Meli et al., 2002, Rusan et al., 2007).

However, while the reuse of TWW in agriculture has several benefits, the high salt concentration that characterizes TWW may have negative effects on the soil physical properties, inducing soil salinization and consequently causing a reduction in yield and uptake by roots (Isayenkov and Maathuis 2019). Therefore, it is worthwhile to evaluate agricultural TWW reuse practices (Farhadkhani et al., 2018).

This article is protected by copyright. All rights reserved. 
While accurate monitoring practices aid in identifying the differences in soil properties resulting from the application of different qualities of water and irrigation management strategies, accurate results are detected only over time.

In this regard, it is paramount to rely on models able to support the application of appropriate schedules that account for water quality parameters and soil properties, balancing water requirements and deliveries (Kamble and Irmak 2011) for increasing plant growth (Chartzoulakis 2015), and controlling water fluxes and the transport of salts in the vadose zone and beyond the root zone. The degradation of the quality of groundwater due to salinization processes is one of the key issues (Greene et al., 2016).

In fact, a combination of monitoring and modeling techniques is needed to both understand potential adverse impacts and assess the accuracy of the models.

Regarding monitoring practices, previous research has shown that salinity reduces the uptake of several nutrients (e.g., nitrate and phosphorous) by roots, the soil infiltration rate and aeration. In addition, the soil $\mathrm{pH}$ changes according to soil structure, irrigation scheduling and depth (Oster 1985; Abedi-Koupai et al. 2006) and influences the availability of nutrients and the mineralization of organic matter. For example, organic matter content and soil aggregates can affect the capacity of soil to retain water, the soil infiltration and drainage properties, and the quality and fertility. As mentioned above, TWW contains abundant nutrient pools and salts, suspended solids and dissolved organic matter (Mohammad and Mazahreh 2003), but its use for irrigation may have unfavorable effects on soil properties on a long-term basis (Levy and Assouline 2011). These typical characteristics that distinguish TWW from conventional waters reduce the soil hydraulic conductivity (Bedbabis et al. 2014; Gharaibeh et al. 2007; Gonçalves et al. 2007) and change the distribution of pore sizes as a result of the expansion or dispersion 
of soil particles (Adhikari et al. 2015; Abedi-Koupai et al. 2006; Coppola et al. 2003; Halliwell et al. 2001).

Regarding irrigation scheduling, the ongoing proposed strategies for TWW reuse continue to rely on the traditional modeling of irrigation plans that are intended for conventional water sources. They are mostly based on the evapotranspiration demand, which means that the delivered water to the crops is obtained as the difference between seasonal evapotranspiration and precipitation deficit (Libutti et al. 2018; Khelil et al. 2017; Lonigro et al. 2015). Traditional irrigation plans can also be based on the soil water depletion ratio, as irrigation occurs whenever the soil water deficit in the effective root zone reaches a predefined limit value of the total available water (TAW) (Allen et al. 1998). This kind of approach does not take into account the soil and water quality. Accordingly, additional important parameters are needed to propose adequate TWW irrigation management, such as the quality of the applied TWW, the soil water and salinity levels, and the presence of pathogens (e.g., Escherichia coli).

New modeling techniques are required to assist in the selection of the appropriate irrigation practices for TWW reuse and to understand a priori the complex responses. This will enable the modification of the current farm management practices and the adoption of an irrigation strategy adequate for TWW reuse that minimizes adverse impacts. Among several scenarios that can be simulated, those based on minimizing salt build-up in the root zone and preventing the leaching of readily leachable nutrients or contaminants are the most accurate (Magesan and Wang 2003).

Based on all the above, the current study reports on the development of the safe irrigation management (SIM) model, with the view of simulating accurate irrigation management scenarios and schedules tailored specifically to TWW reuse. SIM comprises a set of subroutines that account for water quality parameters and soil properties while This article is protected by copyright. All rights reserved. 
combining water and salt conservation equations and enables the comparison of conventional and TWW irrigation management scenarios, allowing an understanding of how actual practices could be improved to enable irrigation with TWW.

These challenges are pursuant to a range of themes encompassed by the Sustainable Development Goals, in particular target 2.4, which seeks to implement resilient agricultural practices that increase productivity and production, strengthen the capacity for adaptation to climate change, and progressively improve land and soil quality, as well as targets 6.3 and 6.4, which seek to improve water quality by reducing pollution, halving the proportion of untreated wastewater, substantially increasing recycling and safe reuse, substantially increasing water-use efficiency and ensuring sustainable withdrawals to address water scarcity.

The new model was applied to define the most accurate irrigation strategy with TWW on citrus in Souss-Massa, a Moroccan region that in recent years has experienced a growing deficit in its water resources; citrus is a strategic crop that contributes to almost $60 \%$ of national fruit and vegetable exports in Morocco. Field-collected data were used to calibrate SIM as per the freshwater-related outputs, while observed data available in the literature were used to calibrate the related outputs of TWW due to the lack of monitoring practices on citrus under TWW in open fields in Morocco.

\section{Materials and methods}

\subsection{The study area}

The Souss-Massa region (Agadir, Morocco) (Figure 1) extends over 51642 km² with a population of 2676847 according to the 2014 Moroccan census. It is characterized by a semiarid to subdesert climate, softened by the current from the Atlantic Ocean and the mountainous barrier of the Anti-Atlas chain, acting as a protection against desert influence. The temperatures are moderate, with an annual This article is protected by copyright. All rights reserved. 
average of approximately $19^{\circ} \mathrm{C}$, an average maximum of approximately $27^{\circ} \mathrm{C}$ and a minimum of approximately $11^{\circ} \mathrm{C}$. The region is one of the main contributors to the economic development of the kingdom, providing $12.3 \%$ of the total national GDP with a predominance of agriculture and services. Analysis of the agricultural sector shows the fruit and vegetable production in the region, especially citrus (Elomary et al., 2016). Among a variety of fruits, citrus is the most produced and consumed in Morocco and in more than 140 countries in the world. According to FAO statistical data (FAO, 2017), the main producing country is China, which accounts for $25.73 \%$ of world production, followed by Brazil, with 13.83\%, while Morocco reached 2.23 million tons, or $1.61 \%$ of the total world production. With an average national production of approximately 2 million tons/year and an area of 125000 ha, citrus plantations occupy 40343 ha in Souss-Massa, representing the third of the total citrus area in Morocco. Thirty percent of the farms in the region are larger than five hectares and represent 99\% of the total area (Abaouz 2013).

Citrus exports from Morocco are approximately 500000 tons a year and represent a major source of foreign exchange, with the equivalent of nearly 315 million dollars a year (Maroc-citrus 2017) contributing to the creation of 21 million working days per year. However, the intensive development of agricultural production is increasingly constrained by water resource scarcity. Rainfall is irregular and does not exceed $200 \mathrm{~mm}$ per year in the plains and $600 \mathrm{~mm}$ per year on the mountain summits (Hermas 2017). This situation is exacerbated by prolonged and severe droughts that are becoming recurrent and an increasingly alarming groundwater condition, showing an average deficit of 150 million $\mathrm{m}^{3}$ /year and a groundwater level decrease of approximately 1-2 m/year.

This article is protected by copyright. All rights reserved. 
Morocco has an ambitious agricultural policy aimed at modernizing agriculture and promoting agricultural investments while focusing on water economy management. In this context, 80 million $\mathrm{m}^{3}$ of TWW, representing $45 \%$ of the total volume of TWW, is being used in agriculture in Morocco, but to date, citrus cultivation is kept out of the loop.

To conduct the current study, field data were provided by citrus farmers in the Souss-Massa region, and an experimental test was carried out on an area of 3.16 ha planted with citrus of the "Nadorcott" variety. The trees were almost 6 years old and planted at a spacing of approximately $3 \times 5$ meters for a total of 2112 trees. Field and experimental data refer to freshwater irrigation practices and fertilization. In addition, the water quality data required to simulate irrigation scenarios with TWW and to assess the effects on soil salinity and citrus response were collected from the local wastewater treatment plant.

\subsection{Safe irrigation management model development and application}

The fate in the soil of water and nutrients derived from irrigation with TWW is governed by numerous processes and factors. Safe irrigation management is a tool developed and applied to predict these processes and to identify critical factors related to water qualities and soil properties. It is used to extrapolate the results of different irrigation and fertigation management schemes, allowing for the analysis of alternative scenarios of management strategies in terms of the impact on achieved yield and soil properties, in addition to environmental risks.

The SIM model is based on a one-dimensional daily basis water and nutrient balance model, using the single crop coefficient approach (single Kc) and accounting for the water and soil quality parameters, bacterial movement and risk of infection.

This article is protected by copyright. All rights reserved. 
The model simulates the water and salt fluxes in the soil. While water balance is calculated as the difference between water inputs (irrigation and precipitation) and outputs (evapotranspiration, runoff and drainage), the initial electrical conductivity of the saturated soil extract $\left(\mathrm{EC}_{\mathrm{e}}\right)$, the electrical conductivity of water $\left(\mathrm{EC}_{\mathrm{w}}\right)$ and the minimum and maximum salt tolerance levels of the selected crop $\left(\mathrm{EC}_{\min }\right.$ and $\left.\mathrm{EC}_{\max }\right)$ are inputted to simulate the stress induced by salinity and accordingly define an irrigation schedule plan. The SIM model is thoroughly described in Appendix I.

\subsection{Reliability testing of the SIM model}

The initial soil conditions of the case study were characterized, and the following required parameters were input: soil temperature; water content; electrical conductivity; bacterial colony forming unit (CFU) content in the root zone and water; organic matter; residual organic materials; and nitrate, ammonia and phosphorus contents. Input data concerning freshwater (FW) quality parameters, citrus crop, irrigation and fertilization scheduling with FW, and $\mathrm{N}$ and $\mathrm{P}$ soil residuals from the previous irrigation season were determined and provided by the local farmers. Quality parameters of the TWW were collected from the wastewater treatment plant and climate data from the meteorological station located in the study area. These latter parameters were imported into the SIM model and used to calculate $\mathrm{ET}_{0}$ using the Penman-Monteith equation. Table 1 shows the main TWW and soil parameters of the analysis for the 2017 growing season. With the aim of testing the outputs of the SIM model related to the effects of different water qualities (FW and TWW) on citrus yield and irrigation management practices, several irrigation scenarios were simulated. These scenarios reproduced the irrigation management strategy actually applied by farmers and the strategy suggested by the model. Hereafter, the management scenarios considering the fixed depletion option are reported. In this scenario, irrigation is cut off only when the soil moisture deficit reaches 
$25 \%$ of the total water holding capacity. This scenario, reproduced for both FW and TWW irrigation management, was selected for illustration, as it showed the most significant results in terms of water volumes applied and potential achievable yield. Since citrus is a perennial crop, the quantitative microbial risk analysis (QMRA) module was not applied in this study, and a negligible level of risk of exposure to TWW was assumed.

Under these assumptions, the following four scenarios were considered, and the model reliability was assessed:

1: Farmer's management strategy under freshwater - Scenario F-FW

2: Farmer’s management strategy under treated wastewater - Scenario F-TWW

3: Model management strategy under freshwater - Scenario M-FW

4: Model management strategy under treated wastewater - Scenario M-TWW

The first simulation exactly reproduced the irrigation and fertilization management applied by the farmers (F) in the region (F-FW). Then, the same strategy was reproduced with TWW (F-TWW). Consequently, these 2 scenarios were compared to those suggested by SIM (M-FW and M-TWW) under the same initial conditions. This procedure enabled the illustration of the inadequacy of applying the practices commonly performed by farmers for irrigation with FW when TWW is used. Alternatively, SIM provided a water and fertilization management strategy adequate for TWW reuse based on water quality and soil properties and minimized drainage fluxes, which are considered potential threats to groundwater quality.

A calibration procedure was carried out to optimize the performance of the SIM model by comparing the observed and simulated data. The performance of SIM at This article is protected by copyright. All rights reserved. 
calibration was assessed based on a standard statistical technique that considers the calculation of the root mean square error (RMSE) to predict errors. Details are reported in Appendix II.

\section{Results and Discussion}

The SIM model simulated water inflows and outflows based on the processes represented by a bucket model. Figure 2 shows that the water balances resulting from farmer management (scenarios 1 \& 2) and those reproduced by the model are similar and do not withstand the different qualities of the applied water (FW and TWW) or their potential impacts. The soil system is the same, and the irrigation volumes are scheduled similarly. Conversely, the irrigation schedule proposed by the SIM model accounted for the water quality, and consequently, a different management strategy was proposed.

The farmer management strategy resulted in high drainage volumes at the beginning of the irrigation season, while the SIM strategy delayed the drainage, applying less frequent irrigation events with higher doses. When TWW is used, this strategy generates a leaching fraction that moves the water and, consequently, salts below the root zone and to redistributes them in the peripheral area of the root system, reducing saltinduced crop stress.

Figure 2a shows the water balance components relative to the farmers' applied strategy with FW and TWW (scenarios 1 \& 2). In 2017, the total amount of rainfall did not exceed $80 \mathrm{~mm}$ in the region (44,8 $\mathrm{mm}$ from 10 to 15 February 2017). Consequently, irrigation events were necessary to meet water requirements, resulting in a total irrigation amount of $970 \mathrm{~mm}$, of which drainage accounted for $301 \mathrm{~mm}$. Irrigation is managed by farmers on a daily basis, where small doses of water not exceeding $5 \mathrm{~mm}$ in the peak period are applied. Moreover, Figure 2a shows the soil moisture deficit (SMD), which 
gradually decreases with irrigation and rainfall events. This deficit is kept above the RAW threshold throughout the entire cycle, which indicates that irrigation scheduling does not induce any water stress. Crop evapotranspiration varies throughout the cycle and reaches its maximum during summer months; thus, the daily irrigation volumes increase to accordingly account for the daily losses. Although this irrigation management approach maintains permanently wet soil, decreases the soil moisture deficit and prevents water stress, it may induce lateral water and salt movement and lead to the accumulation of salts in the soil (Rhoades et al., 1973).

The management strategy suggested by SIM under the same initial conditions resulted in a total irrigation volume of $691 \mathrm{~mm}$, of which drainage accounted for $26 \mathrm{~mm}$. Figure $2 \mathrm{~b}$ shows the water balance outputs of the M-FW and M-TWW simulations (scenarios $3 \& 4$ ). According to this strategy, irrigation events are less frequent, but greater amounts of water are applied. The soil moisture deficit is kept above the RAW threshold during the entire cycle to restore the soil water content to field capacity. On the other hand, drainage is quite low and only occurs at the beginning of the growing season when the soil is relatively dry and irrigation is accompanied by high rainfall. By reducing the drainage fluxes, the SIM strategy saves $279 \mathrm{~mm}$ of water compared to that under the farmers’ management without causing any decrease in yield. In fact, by considering larger intervals between irrigation events, the SIM strategy reduces salt accumulation in the root zone and keeps salt concentrations at levels that are acceptable by the crop. This strategy is convenient for farmers because it fosters a longer operation of the irrigation systems to deliver larger amounts of water, reducing the clogging problems that are more frequent with TWW.

To assess the accuracy of the irrigation strategy suggested by SIM, a relative irrigation supply (RIS) index was calculated on a monthly basis. RIS is expressed as the This article is protected by copyright. All rights reserved. 
ratio between the irrigation water actually applied (registered data) and the irrigation requirement (modeled data). This ratio was greater than 1 in June through October, indicating that the farmers' strategy overestimated the water demand, while in January through June, the RIS index was lower than or equal to 1, indicating that farmers provided smaller or equal amounts to those simulated by the SIM model, as shown in Figure 3.

Figure 4a clearly shows the difference in terms of drained volumes resulting from the $\mathrm{F}$ and $\mathrm{M}$ management strategies. Drainage starts around the middle of the growing season in F-FW \& F-TWW. This is linked to the water inputs (irrigation and rainfall) being larger than the crop evapotranspiration. However, as already stated, the M-FW \& M-TWW scenarios result in a smaller drainage volume occurring at the beginning of the growing season, coinciding with important precipitation (on 11 and 12 February 2017, with $16 \mathrm{~mm}$ and $26 \mathrm{~mm}$, respectively) coupled with large irrigation volumes, applied to account for the initial soil drought. In fact, the initial soil moisture deficit was estimated at $50 \%$, requiring intense irrigation at the beginning of the cycle to restore the soil water content.

The effects of M-TWW on soil properties were investigated. No persistent salt accumulation is shown due to the rainfall recorded in 2017. However, M-TWW predictions have demonstrated that after several irrigation events, a decreased infiltration rate occurs compared to that of the M-FW. This decrease is attributed to the change in the distribution of pore sizes (Gharaibeh et al., 2007).

The ECe in the M-TWW scenario varies according to irrigation and nutrient management (Figure 4b). Conventional sewage treatment partially eliminates salts, so they remain in irrigation water (Tarchitzky et al. 1999), but the time needed for soil salinization to be shown under real agricultural conditions is not well known. This article is protected by copyright. All rights reserved. 
Under SIM (Figure 4b), soil salinity starts to increase with time for the F-TWW and M-TWW management strategies, with a difference in the pattern of increase. In the first case, soil salinity gradually and steadily increases until reaching a maximum around the middle of the cycle and then starts to gradually decrease. The inflection point corresponds to the peak period, when crops require substantial amounts of water and fruit maturity processes are at their maximum.

SIM assumes that higher amounts of water should be supplied to help gradually decrease soil salinity. Consequently, the SIM schedule considers longer intervals between irrigation events and greater application volumes. This strategy allows for a lateral redistribution of water in the soil and for a slowing down of the drainage fluxes that help contain groundwater contamination.

To understand if part of the accumulated salts may be leached into deeper layers, the daily leaching fraction (LF) was estimated. The LF is the excess water applied during an irrigation event that infiltrates past the root zone to prevent average soil salinity from rising above specific acceptable thresholds. It is expressed as the ratio between $S_{L}$ (the leached mass of salts) and $\mathrm{S}_{\mathrm{T}}$ (the total salt mass in the soil) multiplied by the irrigation water volume (see Appendix I).

Since $\mathrm{S}_{\mathrm{L}}$ is the difference between ECe and the electrical conductivity threshold below which the plant yield is not affected, the LF is sensitive to the amount of irrigation water applied and to the threshold tolerance of the crop. Citrus is generally considered to be salt sensitive (Bernstein 1980; Furr and Ream 1969; Kirkpatrick and Bitters 1969). Figure 4c shows that the irrigation management set by SIM produced an LF quite higher than that produced by farmers, which was estimated by accounting for soil characteristics to induce lateral water and salt movement and thus to reduce the fluxes beyond the root zone.

This article is protected by copyright. All rights reserved. 
In the case of the farmers' strategy, the daily water uptake contributed to the salts being slowly pushed down and to their accumulation in the soil. Although the soil salinity was high during the vegetative stage, it did not influence the citrus response in terms of yield, as the salt distribution pattern was induced both vertically and horizontally.

In terms of nutrient balance and uptake, SIM showed a trend for nitrogen $(\mathrm{N})$ and phosphorus (P) for both strategies ( $\mathrm{F}$ and $\mathrm{M}$ ) (Figure 5). The high concentrations of $\mathrm{N}$ and $\mathrm{P}$ in TWW positively influenced citrus nutrition and rendered especially the concentration of P closer to the optimum level (Pereira et al. 2011).

It was observed that TWW constitutes a reliable nutrient source for crops (Bedbabis et al. 2014, Jimenez-Cisneros 1995) and allows for a partial reduction in the use of chemical fertilizers (Gil and Ulloa 1997) and improvements in crop yields (Coppola et al. 2005).

A comparison of the simulation outputs with FW and TWW supports these observations and shows that TWW allows for important savings in fertilizer amounts, namely, a 30\% reduction in the use of ammonitrate as inorganic nitrogen fertilizer and a $25 \%$ reduction in the use of monoammonium phosphate (MAP), a complex fertilizer containing nitrogen (11\%) and phosphate (52\%).

The simulated trends of $\mathrm{N}$ and $\mathrm{P}$ uptake (Figure 5a) show that the SIM strategy provided adequate macronutrients over time. The uptake rates of $\mathrm{N}$ and $\mathrm{P}$ responded to citrus vegetative stage needs, demonstrating that irrigation with TWW was able to provide adequate $\mathrm{N}$ and $\mathrm{P}$. The dashed black and blue lines show the trends of $\mathrm{N}$ and $\mathrm{P}$, respectively, showing that $\mathrm{N}$ uptake is adjusted to crop needs (Lado et al., 2012), with higher rates at the beginning and the middle of the irrigation season (from February to 
August) that decrease at the end of the season (1.4 to $0.2 \mathrm{~kg} / \mathrm{ha} /$ day). The trend of the $\mathrm{P}$ uptake rate shows an equal increase at the beginning up to the middle of the season but rapidly decreases later on, reaching values between 0.15 and $0.05 \mathrm{~kg} / \mathrm{ha} / \mathrm{day}$.

When FW is used and the same seasonal irrigation volumes as those of TWW are applied, the $\mathrm{N}$ uptake (continuous black line) is constant over the irrigation season with an average value of $0.8 \mathrm{~kg} / \mathrm{ha} /$ day, while $\mathrm{P}$ uptake (blue line) decreases over time, with average values oscillating between 0.08 and $0.04 \mathrm{~kg} / \mathrm{ha} / \mathrm{day}$. This may be explained by the fact that FW management would have required additional fertilization events to meet the nutrient needs of citrus. In summary, irrigating citrus trees with TWW may provide significant fertilizer savings (Maestre-Valero et al., 2019, Pedrero et al., 2016).

Figure 5b refers to the farmer strategy applied for both FW and TWW and shows how $\mathrm{N}$ is taken up at a higher rate than $\mathrm{P}$ at the beginning of the cycle, given that the crop is restoring its foliar system; then, toward the end of the cycle, $\mathrm{P}$ uptake is more important due to the physiological change in development stages. The farmer management strategy induces a high drainage flux at the beginning of the irrigation season, as explained earlier; when TWW is used, this flux induces a high loss of $\mathrm{N}$ provided by the water, and consequently, a decreasing trend of $\mathrm{N}$ uptake is observed, going from 1.60 to $0.2 \mathrm{~kg} / \mathrm{ha} /$ day.

In contrast to $\mathrm{N}, \mathrm{P}$ moves slowly in the soil and is not easily carried by water, which results in a higher uptake by the crop. The continuous and dashed blue lines represent the trend of $\mathrm{P}$ uptake by the crop under the F-FW and F-TWW strategies, respectively. A high rate is shown throughout the entire irrigation season, with an average value of approximately $0.2 \mathrm{~kg} / \mathrm{ha} /$ day and a peak of $0.32 \mathrm{~kg} / \mathrm{ha} / \mathrm{day}$ in the middle of the irrigation season for F-FW, while P uptake remained low under F-TWW because no fertilization occurred under TWW management. The SIM model only accounts for $\mathrm{N}$ This article is protected by copyright. All rights reserved. 
and P, considering that they are the key fertilizing elements, and can be used as indicators for fertilization.

It is worth mentioning that environmental impacts were assessed by estimating the E. coli concentration as a proportion of the total volume of drainage water, even though data are not shown. TWW application resulted in increased microbial contamination of the soil over time under the F-TWW strategy, while a low E. coli concentration was observed with the M-TWW strategy, suggesting that the latter strategy can be field tested for citrus at a small scale.

In terms of the impact on yield, many studies state that saline waters might reduce yield (Murkute et al. 2005; Morgan 2011) compared to that of conventional water. Assuming that the yield reduction in the present study relies on the impact of the soil salinity, the use of TWW induced a yield decrease of $4 \%$ under the M scenario, while the F-TWW scenario induced greater decreases of $23 \%$. This is due to the application of an irrigation plan based on farmer experience with FW, where the high frequency of irrigation events induced high salinity concentrations in the soil.

Finally, the accuracy of the SIM simulations and results were tested, and a calibration procedure was applied (see Appendix II). As shown in Figure 4d, SIM shows good agreement with the observed data collected from previous studies, as indicated by smaller RMSE and higher $\mathrm{R}^{2}$ values. The indicators show the appropriateness of considering ECe to assess the model performance rather than SWC (see Table 1 in Appendix II). In fact, SIM outputs generated for the M-TWW scenario show $\mathrm{RMSE}=0.19 \mathrm{dSm}^{-1}$ and $\mathrm{R}^{2}=0.92$ for ECe.

Furthermore, the simulated salt dynamics induced a nonuniform distribution through the soil profile and could have slightly enhanced the deviations between the This article is protected by copyright. All rights reserved. 
measured literature study data (LitS M) and simulated data, but still are in good agreement. The causes of the discrepancies might be partially attributed to the spatial heterogeneity and observation errors and to the comparison of different experimental trials.

Overall, SIM was able to provide a proper irrigation management strategy accounting for water quality. This approach minimizes the risks derived from microbial contamination and from salt and macroelement accumulation in the root zone and from the downward fluxes toward the groundwater. SIM enables the proper reuse of TWW in irrigation, an alternative nutrient-rich resource that may contribute to alleviating the pressure on freshwater.

\section{Conclusions}

The reuse of TWW, especially in agriculture, is an attractive and pragmatic solution for water scarcity that substantially alleviates pressure on water resources (Toze 2006; Zhang and Liu 1989) and that leads to additional agronomic benefits associated with the high nutritive value of TWW, which may enhance plant growth and poor soil productivity and fertility while reducing fertilizer application rates (Kiziloglu et al. 2007). However, achieving success in crop production largely depends on the adoption of appropriate management strategies that, in addition to optimizing yield and maintaining soil productivity, safeguard the environment in the long term. From this perspective, these strategies gain even more ground when TWW is reused.

The safe irrigation management model developed in this research demonstrated that irrigation management strategies should be tailored to the quality of the irrigation water. Calibrated and applied to predict the effects of TWW on soil characteristics and citrus yield in Souss-Massa, Morocco, the analysis of the reuse scenarios confirms that the irrigation practices commonly performed by farmers with FW are not extendible to This article is protected by copyright. All rights reserved. 
TWW reuse, while the scenarios proposed by the model that considered the water quality parameters were able to be adapted according to the irrigation strategy, allowing for the lateral movement of water and salts and slowing down the drainage fluxes toward the groundwater.

More specifically, the results showed that the management strategy proposed by the SIM model withdraws approximately $71 \%$ and drains $8.6 \%$ of the irrigation water volumes compared to those of the farmers' strategy. For the specific case of TWW, the SIM strategy resulted in a slight yield decrease of approximately $4 \%$, compared to the 23\% decrease derived from the farmers' traditional strategy and allowed for great savings in terms of fertilizing elements. Moreover, the SIM model simulated E. coli movement and assessed the related environmental impact. Increased microbial contamination of the soil over time was demonstrated under the farmer strategy, while a concentration below the threshold was achieved with the SIM strategy.

Although determining the best irrigation management strategy with TWW cannot be achieved only through modeling, and although the conditions and assumptions under which the results were obtained can change in the future, these findings show that the SIM model is an effective and powerful tool that capitalizes on the advantages and limits the adverse impacts of TWW reuse. Moreover, these results confirm the appropriateness of using accurate prediction models that enable the adaptation of irrigation strategies to TWW and that the use of such models should be an integral part of the strategies that encourage the use of TWW in irrigated agriculture.

In this regard, establishing a community of practice among countries is a necessary step forward. Combining monitoring and modeling techniques across case studies in the Mediterranean will further validate SIM as an important tool to develop 
strategies since TWW reuse will become the only alternative source for irrigated agriculture in the next 5-10 years, especially in arid and semiarid regions.

\section{References}

Abaouz N. 2013. Etude technico-économique de la production d'un verger de clémentinier dans la région du Souss. In M. I. A. e. V. H. I.-C. H. d. A. D. o. H. Agadir (Ed.).

Abedi-Koupai J, Mostafazadeh-Fard B, Afyuni M, Bagheri M R. 2006. Effect of treated wastewater on soil chemical and physical properties in an arid region. Plant Soil Environ, 52(8): 335.

Adhikari P, Shukla MK, Mexal JG. 2015. Irrigation with treated wastewater: quantification of changes in soil physical and chemical properties. Water Treatment in Developed and Developing Nations: An International Perspective, 271.

Allen RG, Pereira LS, Raes D, Smith M. 1998. Crop evapotranspirationGuidelines for computing crop water requirements-FAO Irrigation and drainage paper 56. FAO, Rome, 300(9), D05109.

Ayers RS, Westcot DW. 1985. Water quality for agriculture (Vol. 29): FAO, Rome.

Bedbabis S, Rouina BB, Boukhris M, Ferrara G. 2014. Effect of irrigation with treated wastewater on soil chemical properties and infiltration rate. J Environ manage, 133:45-50.

Bernstein L. 1969. Salinity factors and their limits for citrus culture. Proc. First Int. Citrus Symp., Univ. California, Riverside. 3:1779-1782.

Borg H, Grimes DW. 1986. Depth Development of Roots with Time: An Empirical Description. Transactions of the ASAE, 29(1):194-0197. DOI: https://doi.org/10.13031/2013.30125

Chartzoulakis K, Bertaki M. 2015. Sustainable water management in agriculture under climate change. Agric. Agric. Sci. Procedia, 4:88-98.

Coppola A, Santini A, Botti P, Vacca S, Comegna V, Severino G. 2005. Methodological approach for evaluating the response of soil hydrological behaviour to irrigation with municipal wastewater. J. Hydrol. 292(1-4):114-134.

Coppola A, Santini A, Botti P, Vacca S. 2003. Urban wastewater effects on water flow and solute transport in soils. J Environ Sci Health, Part A, 38(8):1469-1478.

Crane SR., Moore JA. 1986. Modeling enteric bacterial die-off: A review. Water Air Soil Poll. 27(3):411-439. DOI: 10.1007/bf00649422

Doorenbos J, Kassam AH. 1979. Yield response to water. Irrigation and drainage paper. 33, 257.

This article is protected by copyright. All rights reserved. 
Elomari H., Fallah M., Elmousadik A. 2016. Effect of Irrigation Methods on Water Use Efficiency Applied to Citrus Crop in the Souss Region (Morocco) in the Context of Climate Change (Version 10005643). http://doi.org/10.5281/zenodo.1127120 World Academy of Science, Engineering and Technology International Journal of Agricultural and Biosystems Engineering. 9,12.

FAO 2017. Annual statistics. Rome: Food and Agriculture Organisation of the United Nations.

Farhadkhani M, Nikaeen M, Yadegarfar G, Hatamzadeh M, Pourmohammadbagher H, Sahbaei Z, Rahmani HR. 2018. Effects of irrigation with secondary treated wastewater on physicochemical and microbial properties of soil and produce safety in a semi-arid area. Water Res. 144:356-364. DOI: https://doi.org/10.1016/j.watres.2018.07.047

Furr JR, Ream CL. 1969. Breeding citrus rootstocks for salt tolerance. Proc. 1st Intl. Citrus Symp., Riverside, Calif. 1:373-380.

Gharaibeh M.A., Eltaif N.I., Al-Abdullah B. 2007. Impact of field application of treated wastewater on hydraulic properties of vertisols. Water, Air, Soil Pollut. 181(14):347-353.

Gonçalves RAB, Folegatti MV, Gloaguen TV, Libardi PL, Montes CR, Lucas Y, Melfi AJ. 2007. Hydraulic conductivity of a soil irrigated with treated sewage effluent. Geoderma,

139(1-2).241-248.

Greene R., Timms W., Rengasamy P., Arshad M., Cresswell R. 2016. Soil and Aquifer Salinization: Toward an Integrated Approach for Salinity Management of Groundwater. In: Jakeman A.J., Barreteau O., Hunt R.J., Rinaudo JD., Ross A. (eds) Integrated Groundwater Management. Springer, Cham

Haas CN, Rose JB., Gerba CP 1999. Quantitative microbial risk assessment: John Wiley \& Sons.

Halliwell DJ, Barlow KM, Nash DM. 2001. A review of the effects of wastewater sodium on soil physical properties and their implications for irrigation systems. Soil Res. 39(6):1259-1267.

Hargreaves GH, Samani ZA. 1985. Reference crop evapotranspiration from temperature. Appl Eng Agric. 1(2):96-99.

Hermas H. 2017. Eau: Le Souss-Massa face au défi d'une gestion intégrée et durable. In A. m. d. p. http://mapecology.ma/slider/eau-souss-massa-face-defi-dunegestion-integree-durable/.(Ed.).

IPCC 2014. Synthesis report. Summary for Policymakers. An IPCC Special Report: Climate change 2014:Synthesis Report. Pachauri, Rajendra K, Myles R Allen, Vicente R Barros, John Broome, Wolfgang Cramer, Renate Christ, John A, Church et al.

Isayenkov Stanislav V, Frans Maathuis JM. 2019. Plant Salinity Stress: Many Unanswered Questions Remain. Front Plant Sci. 10:80. DOI:10.3389/fpls.2019.00080.

This article is protected by copyright. All rights reserved. 
Jimenez-Cisneros B. 1995. Wastewater reuse to increase soil productivity. Water Sci Technol. 32(12):173-180.

Kamble B, Irmak A. 2011. Remotely Sensed Evapotranspiration Data Assimilation for Crop Growth Modeling Evapotranspiration: InTech.

Khelil NM, Rejeb S, Destain JP, Xanthoulis D. 2017. Does fertilization practices increase residual nitrate nitrogen in soil irrigated with treated wastewater? An experimental trial on maize. International Journal of Environment, Agriculture and Biotechnology, 2(2):819-830.

Kirkpatrick JD, Bitters WP. 1969. Physiological and morphological response of various citrus rootstocks to salinity. Proc. 1st Int. Citrus Symp. 1:391-399.

Kiziloglu F, Tuean M, Sahin U, Angin I, Anapali O, Okuroglu M. 2007. Effects of wastewater irrigation on soil and cabbage-plant (Brassica olereacea var. capitate cv. Yavola-1) chemical properties. J Plant Nutr Soil Sc. 170:166-172. DOI: 10.1002/jpln.200621971.

Lado M., Bar-Tal A., Azenkot A., Assouline S., Ravina I., Erner Y., Fine P., Dasberg S., Ben-Hur M.Changes in chemical properties of semiarid soils of semiarid soils under long-term secondary treated wastewater irrigation. Soil Sci Soc Am J. 76(4):1358-1369.

Levy GJ, Assouline S. 2011. Physical Aspects. In G. Levy, Fine, P., Bar-Tal, A. (Eds.). (Ed.), Treated Wastewater in Agriculture: Use andIimpacts on the Soil Environment and Crops, first ed. Wiley-Blackwell. p. 306-327.

Li H., Yi J., Zhang J., Zhao Y., Si B., Hill R.L., Lele Cui, and Xiaoyu Liu. 2015. Modeling of soil water and salt dynamics and its effects on root water uptake in Heihe arid wetland, Gansu, China. Water 7, no. 5: 2382-2401.

Libutti A, Cammerino A, Monteleone M. 2018. Risk assessment of soil salinization due to tomato cultivation in mediterranean climate conditions. Water, 10(11):1503.

Lonigro A, Montemurro N, Rubino P, Vergine P, Pollice A. 2015. Reuse Of Treated Municipal Wastewater For Irrigation In Apulia Region: The" IN. TE. RRA" PROJECT. Environ Eng Manag J. 14(7).

Maas EV, Hoffman GJ. 1977. Crop salt tolerance-current assessment. J Irrig Drain Div. 103(2):115-134.

Maestre-Valero, J.F.; González-Ortega, M.J.; Martínez-Álvarez, V.; MartinGorriz, B. 2019. The role of reclaimed water for crop irrigation in southeast Spain. Water Supply.19, 1555-1562.

Magesan GN, Wang H. 2003. Application of municipal and industrial residuals in New Zealand forests: an overview. Soil Res. 41(3):557-569.

MAPMDERF. 2017. L'agriculture Marocaine en chiffres 2016. Maroc: Ministère de l'agriculture, de la pêche maritime, du développement rural et des eaux et forêts..

This article is protected by copyright. All rights reserved. 
Meli S., Porto M., Belligno A., Bufo S.A., Mazzatura A., Scopa A. 2002. Influence of irrigation with lagooned urban wastewater on chemical and microbiological soil parameters in a citrus orchard under Mediterranean condition Science of the Total Environment, 285:69-77

Milano M, Ruelland D, Fernandez S, Dezetter A, Fabre J, Servat E. 2012. Facing climatic and anthropogenic changes in the Mediterranean basin: What will be the medium-term impact on water stress?. Comptes Rendus Acad. Geosciences. 344(9):432440.

Mishra SK, Singh VP. 2003. Soil Conservation Service Curve Number (SCS-CN) Methodology.

Mohammad MJ., Mazahreh N. 2003. Changes in soil fertility parameters in response to irrigation of forage crops with secondary treated wastewater. Commun Soil Sci Plan. 34(9-10):1281-1294.

Morgan KT. 2011. Effects of Reclaimed water on citrus growth and productivity Waste Water-Evaluation and Management: InTech.

Mounzer O, Pedrero-Salcedo F, Nortes PA, Bayona JM, Nicolás-Nicolás E, Alarcón JJ. 2013. Transient soil salinity under the combined effect of reclaimed water and regulated deficit drip irrigation of Mandarin trees. Agr Water Manage. 120:23-29

Murkute AA, Sharma S, Singh SK. 2005. Citrus in terms of soil and water salinity: a review.

Neitsch SL, Arnold JG, Kiniry JR, Williams JR. 2011. Soil and water assessment tool theoretical documentation version 2009: Texas Water Resources Institute.

Obrador B., Moreno-Ostos E., Pretus J.L. 2008. A dynamic model to simulate water level and salinity in a Mediterranean coastal lagoon. Estuaries and coasts 31, 6: 1117-1129.

Oster JD, Rhoades JB. 1985. Water management for salinity and sodicity control. In: Pettygrove, G.S., Asano, T. (Eds.), Irrigation With Reclaimed Municipal Wastewater: A Guidance Manual. Lewis Publishers, Chelsea, MI, USA, p. 7-1-7-20.

Pedrero, F.; Alarcón, J.J.; Nicolás, E.; Intriago, J.C.; Kujawa-Roeleveld, K.; Camposeo, S.; Vivaldi, G.A. 2016. Multidisciplinary Approach on Reclaimed Water Use Projects in Agriculture. In Proceedings of the III Jornada Agua y Sostenibilidad: La Reutilización de Aguas en España y Europa. Pasado, Presente y Futuro.

Pereira BFF, He ZL, Stoffella PJ, Melfi AJ. 2011. Reclaimed wastewater: effects on citrus nutrition. Agr Water Manage. 98(12):1828-1833.

Pimentel D, Pimentel MH. 2007. Food, energy, and society: CRC press.

Reboll V, Cerezo M, Roig A, Flors V, Lapeña L, García-Agustín P. 2000. Influence of wastewater vs groundwater on young Citrus trees. J Sci Food Agric. 80(10):1441-1446.

This article is protected by copyright. All rights reserved. 
Rhoades J.D., Ingvalson R.D., Tucher J.M., Clark M. 1973. Salts in irrigation drainage waters:I Effect of irrigation water composition, leaching fraction, and time of the year on the salt composition of irrigation drainage waters. Soil Science Society America 37:770-774. doi:10.2136/sssaj1973.03615995003700050038x

Rusan et al., 2007 M.J.M. Rusan, S. Hinnawi, L. RousanLong term effect of wastewater irrigation of forage crops on soil and plant quality parameters. Desalination, 215 (2007), pp. 143-152

Tarchitzky J, Golobati Y, Chen Y, Keren R. 1999. Wastewater effects on montmorillonite suspensions and hydraulic properties of sandy soils. Soil Sci Soc Am J. 63(3):554-560.

Thiébault S, Moatti JP. 2016. The Mediterranean Region Under Climate Change. A Scientific Update.

Toze S. 2006. Reuse of effluent water-benefits and risks. Agr Water Manage. 80:140-159. DOI: 10.1016/j.agwat.2005.07.010.

Warrick A.W., Myers D.E., Nielsen D.R. Geostatistical methods applied to soil science. Methods of Soil Analysis: Part 1 Physical and Mineralogical Methods, 5:53-82.

Zhang L, Liu Z. 1989. A methodological research on environmental impact assessment of sewage irrigation region. Chi Environ Sci. 9:298-303

\section{List of Figures}

Figure I.1. Flow-Chart of SIM model

This article is protected by copyright. All rights reserved. 


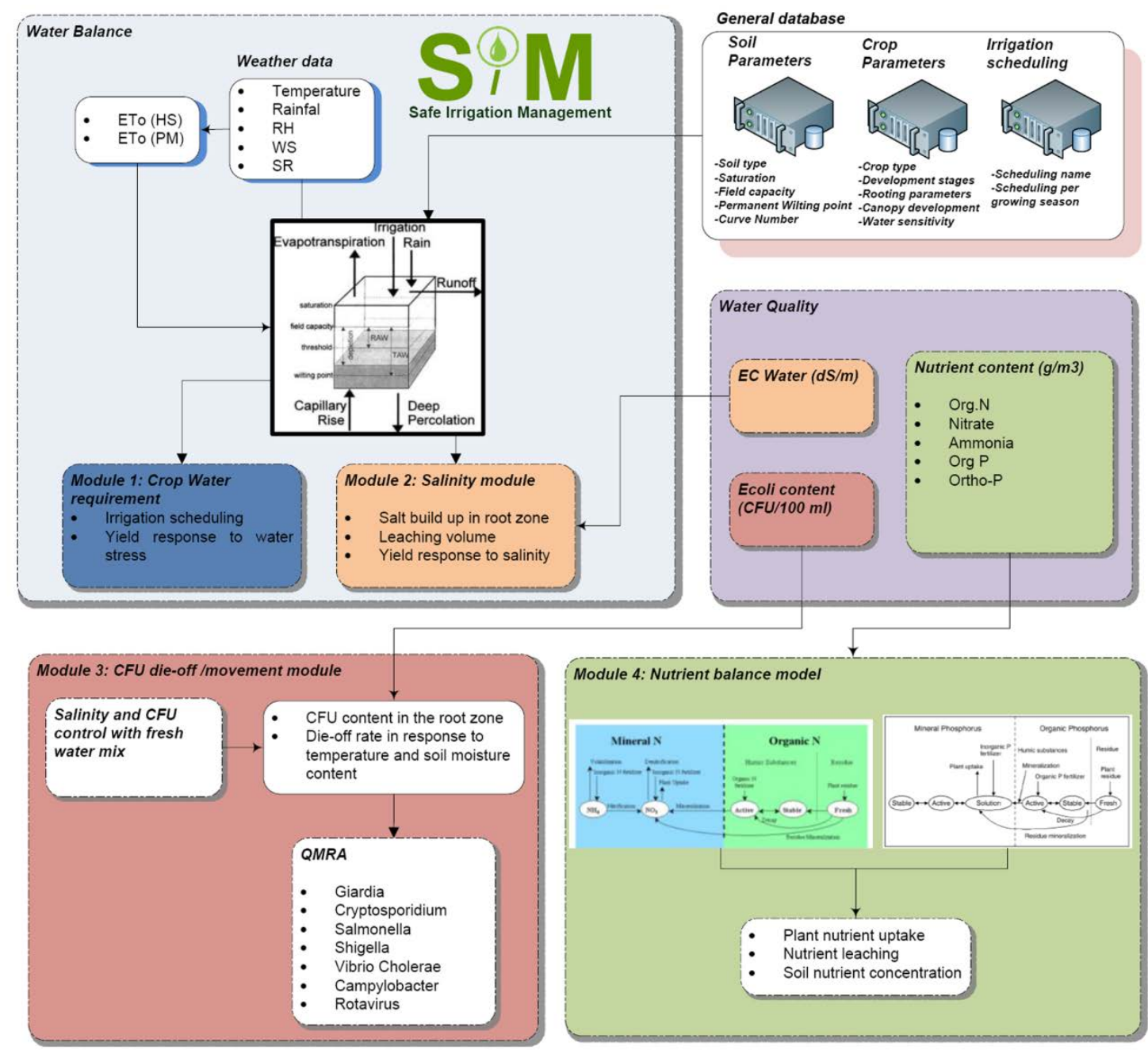

This article is protected by copyright. All rights reserved. 
Figure 1.a) Location of Souss Massa region and b) Citrus production by region. Source: MEYS Emerging Markets Research.

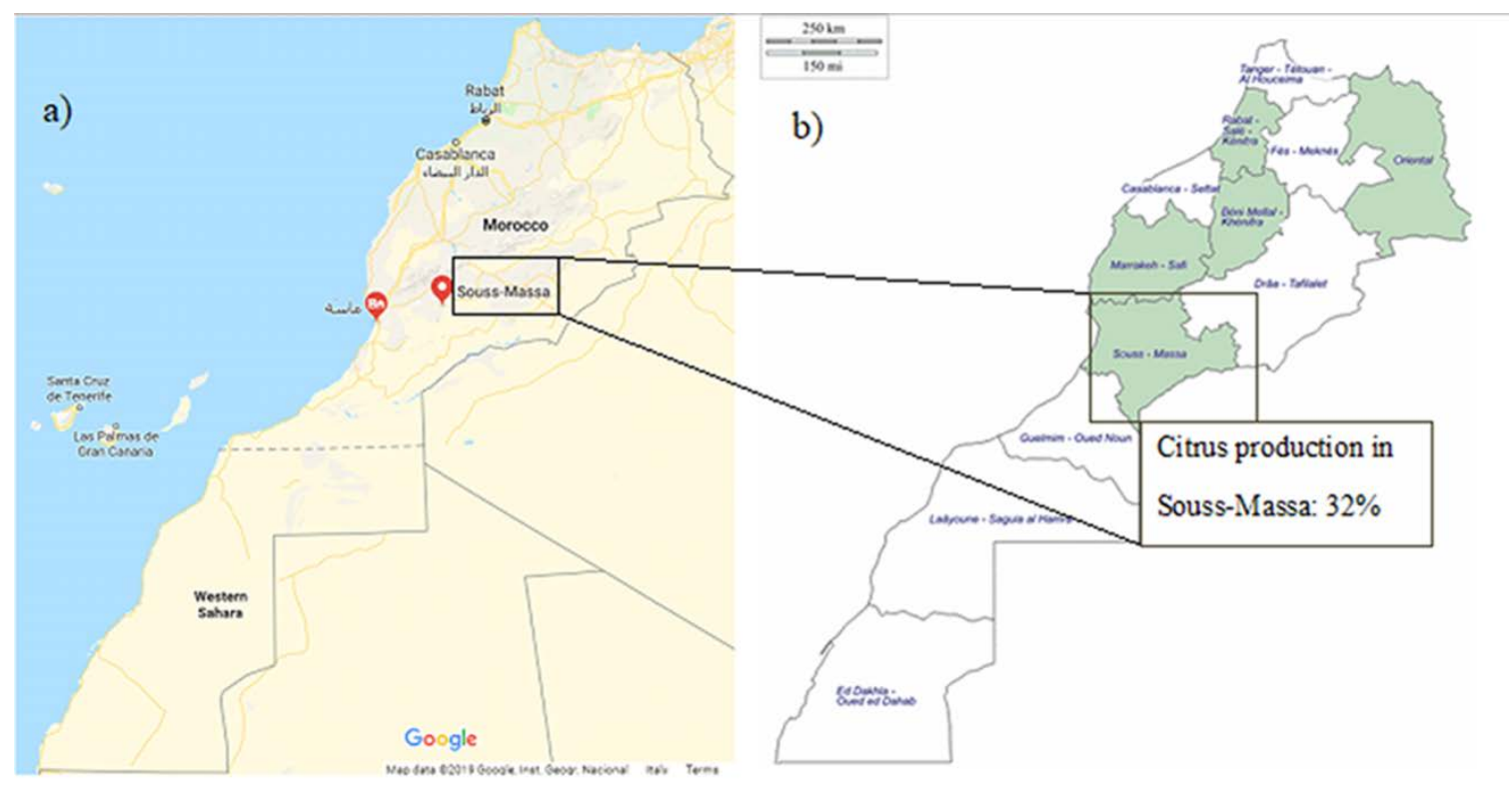

This article is protected by copyright. All rights reserved. 
Figure 2. Water balance components computed by SIM model for 4 simulation scenarios: a) Farmer strategy (F) b) SIM strategy (M) - water balance simulated with both fresh water (FW) and treated wastewater (TWW).
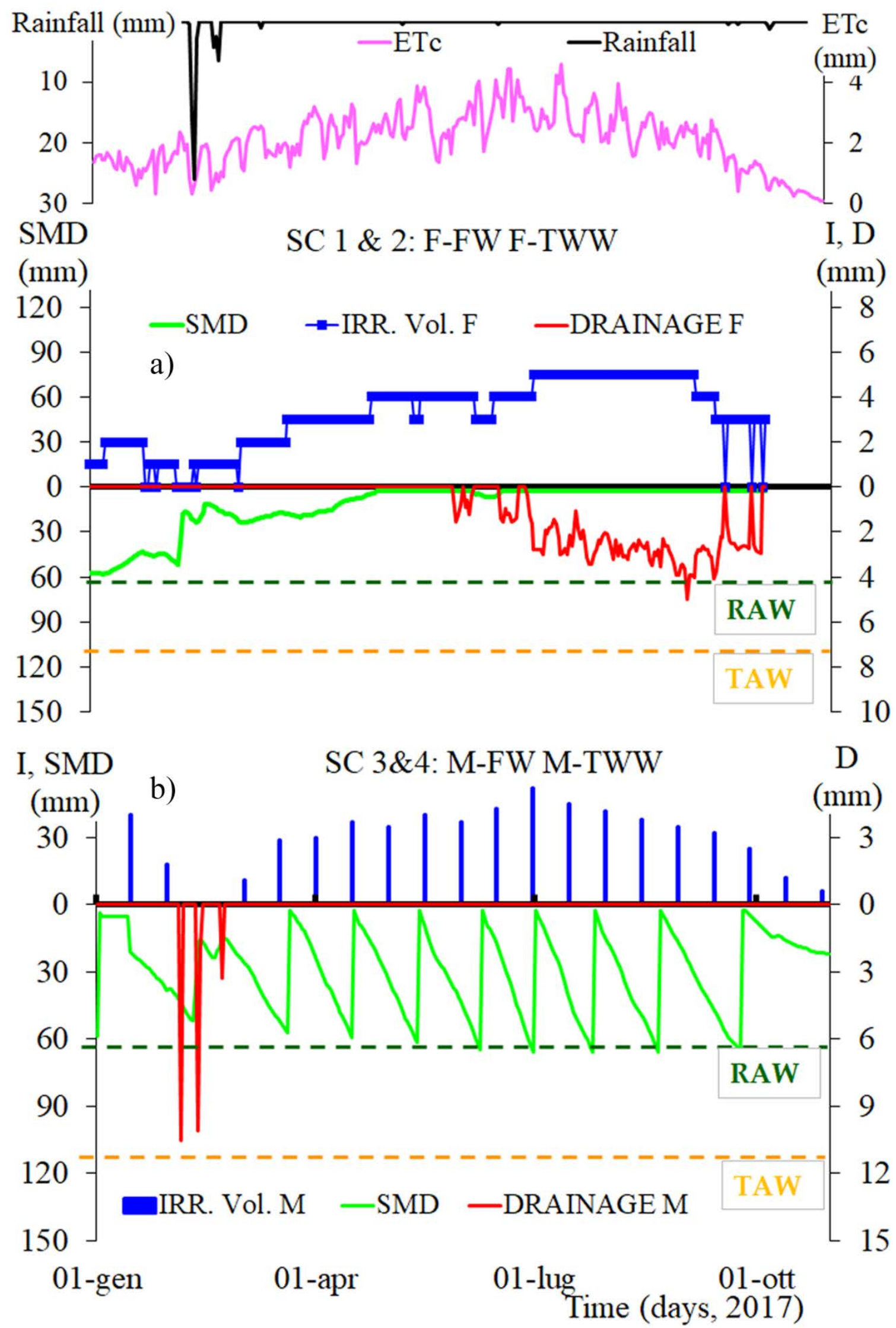

This article is protected by copyright. All rights reserved. 
Figure 3. Relative Irrigation Supply (RIS) calculated as a ratio between irrigation water actually applied (registered data) and irrigation requirement (modelled data) at a monthly basis. The full line represents the reference value 1 to estimate under $(<1)$ and over irrigation $(>1)$ periods.

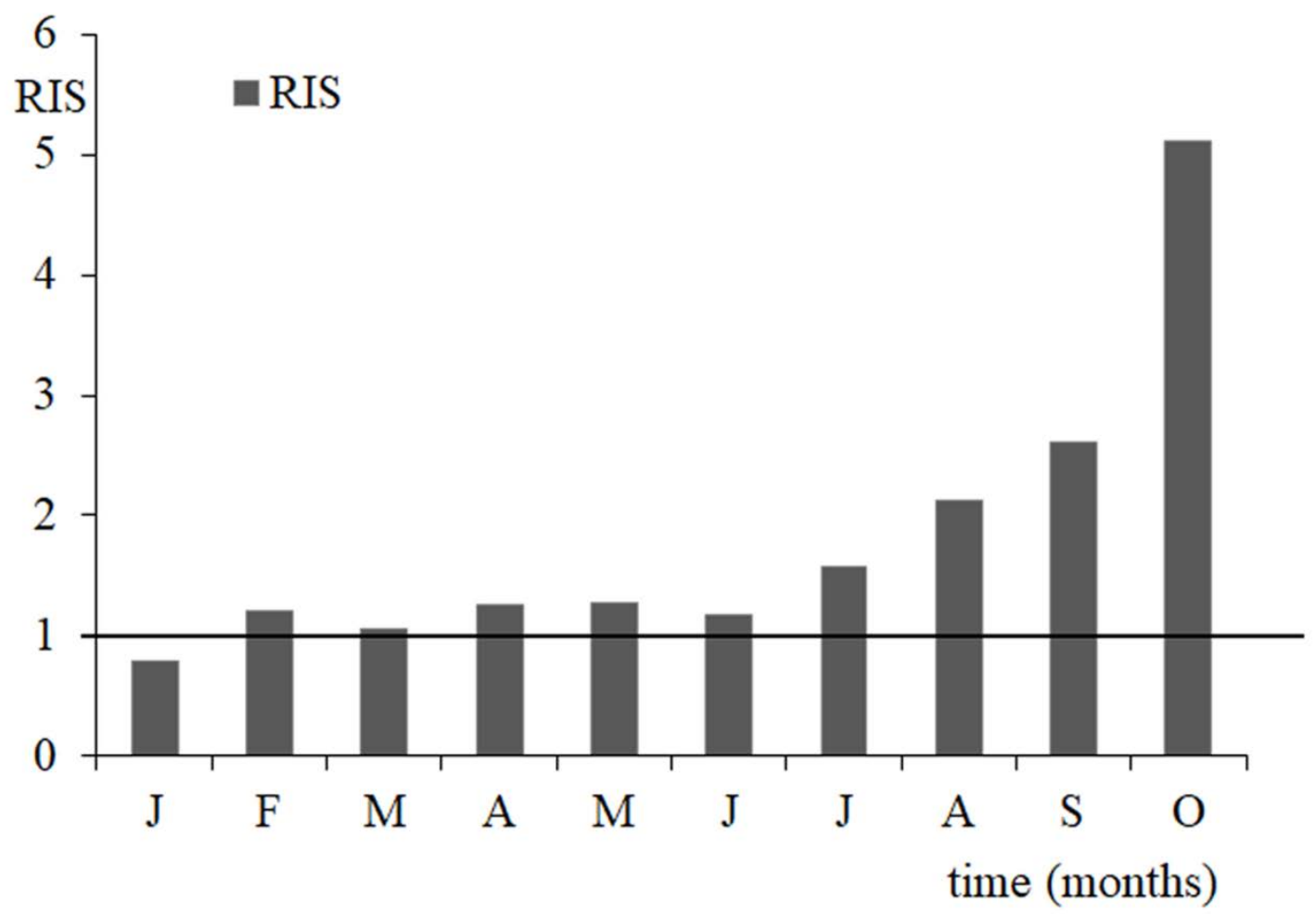

This article is protected by copyright. All rights reserved. 
Figure 4. Impacts on soils simulated as per Farmer (F) and SIM (M) management practices for FW and TWW scenarios. a) drainage volumes: b) soil salinity in terms of electrical conductivity of saturated soil extract (ECe) and c) leaching fraction (LF) over time; d) comparison between ECe values measured and collected from available literature (ECe LitS) and simulated by SIM (ECe M).

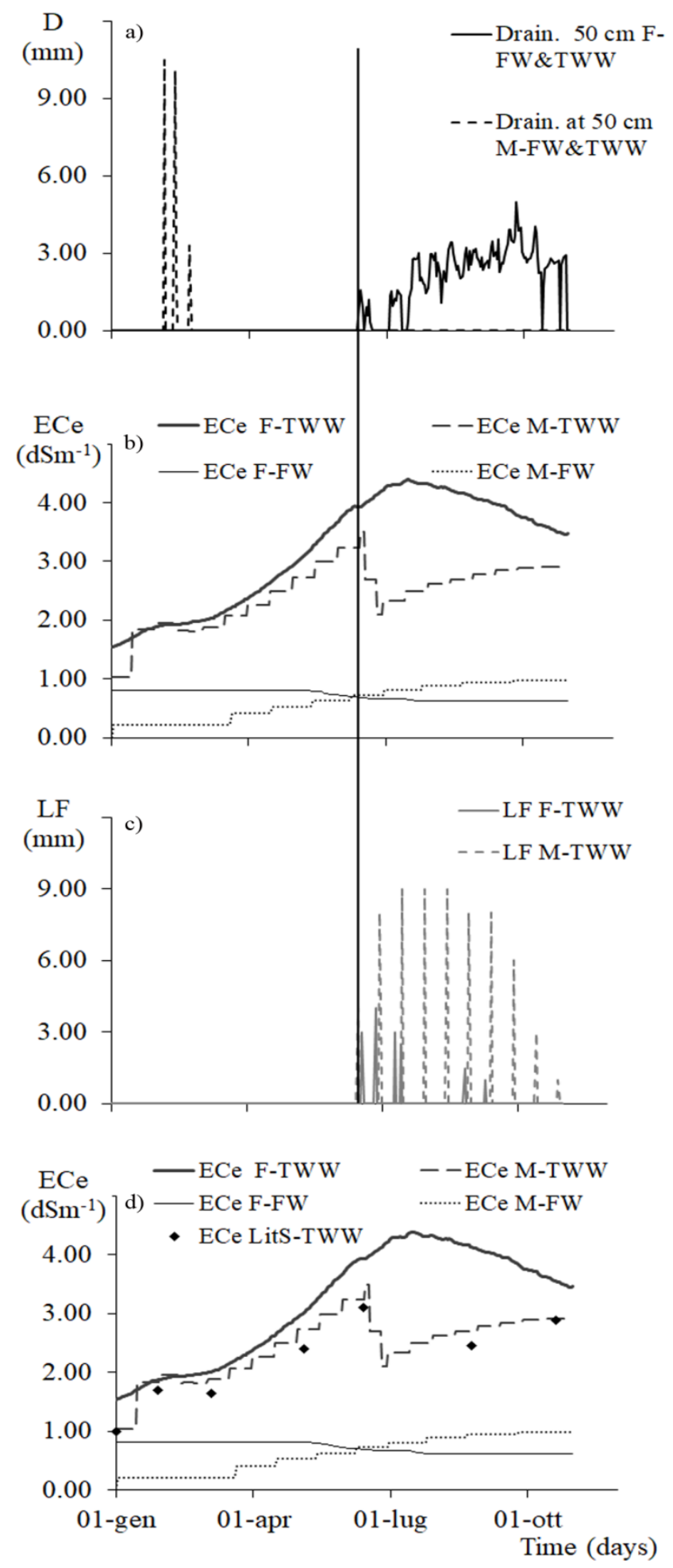

This article is protected by copyright. All rights reserved. 
Figure 5. Nutrients' balance for the 4 scenarios considering a) SIM (M) and b) farmer (F) management strategies with Fresh (FW) and Treated Wastewater (TWW).
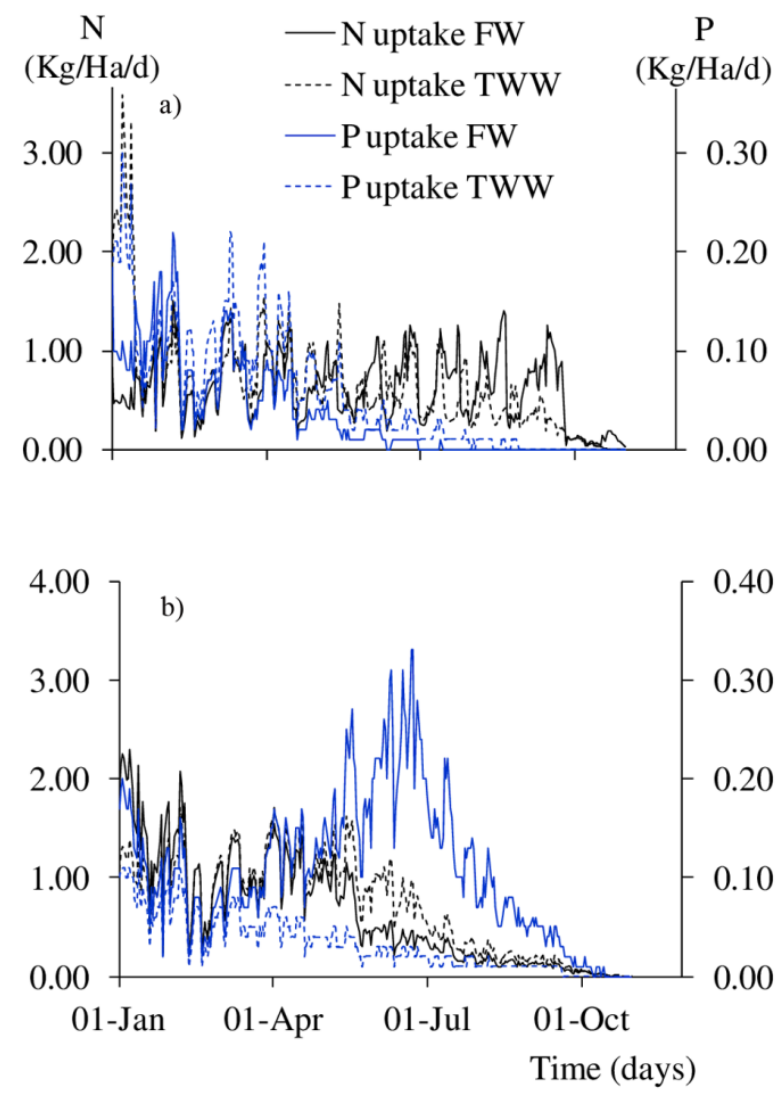

\section{List of Tables}

Table1. Treated Wastewater (TWW) and soil analysis for the study region relative to 2017 growing season

\begin{tabular}{|l|c|}
\hline $\mathrm{pH}$ & 7.08 \\
\hline $\mathrm{EC}_{\mathrm{w}}$ at $25^{\circ} \mathrm{C}\left(\mathrm{dS} \mathrm{m}{ }^{-1}\right)$ & 4.24 \\
\hline Chlore $(\mathrm{mg} / \mathrm{l})$ & 777.84 \\
\hline Bicarbonate $(\mathrm{mg} / \mathrm{l})$ & 493.76 \\
\hline Nitrate $(\mathrm{mg} / \mathrm{l})$ & 230.86 \\
\hline Phosphorus $(\mathrm{mg} / \mathrm{l})$ & 5.65 \\
\hline Calcium $(\mathrm{mg} / \mathrm{l})$ & 449.11 \\
\hline Sodium $(\mathrm{mg} / \mathrm{l})$ & 104.30 \\
\hline Magnesium (mg/l) & 56.63 \\
\hline
\end{tabular}

This article is protected by copyright. All rights reserved. 


\begin{tabular}{|c|c|c|c|}
\hline Potassium (mg/l) & \multicolumn{3}{|c|}{34.30} \\
\hline $\begin{array}{l}\text { Soil texture } \\
\text { (USDA classification) }\end{array}$ & \multicolumn{3}{|c|}{ Sandy clay loam } \\
\hline \multirow{2}{*}{$\begin{array}{l}\text { Particle size distribution } \\
\text { (\%) }\end{array}$} & Clay & Sand & loam \\
\hline & 25 & 50 & 25 \\
\hline $\mathrm{pH}$ & \multicolumn{3}{|l|}{7.50} \\
\hline ECe $\left(\mathrm{dS} \mathrm{m}{ }^{-1}\right)$ at $20^{\circ} \mathrm{C}$ & \multicolumn{3}{|l|}{2.50} \\
\hline
\end{tabular}

This article is protected by copyright. All rights reserved. 